\title{
The Role of Social Capital in Serangan Sub-District, Denpasar-Bali
}

\author{
I Gede Putra Nugraha ${ }^{* *}$, M Made Antara ${ }^{2}$, Made Budiarsa², \\ Syamsul Alam Paturusi ${ }^{2}$ \\ ${ }^{1}$ Tourism Faculty, Udayana University, Bali - Indonesia \\ ${ }^{2}$ Centre of Excellence in Tourism, Udayana University, Bali - Indonesia \\ *Corresponding Author: dedenugraha@ymail.com \\ DOI: https://doi.org/10.24922/eot.v8i1.71458
}

\begin{abstract}
Article Info
Submitted

October $16^{\text {th }} 2020$

Accepted

March $18^{\text {th }} 2021$

Published

March $31^{\text {th }} 2021$
\end{abstract}

\begin{abstract}
Serangan sub-district as a potential area is a representation of Denpasar City Government's policy on environmental conservation, historical and cultural values, the interests of the world of education, and the interests of cultural tourism full of attractions. The purpose of this study is to identify the role of social capital in the development of sustainable tourism in the Serangan Sub-District and to analyze the effect of government roles, community participation, and social capital on destination quality and sustainable tourism development in the Serangan sub-district. The result of this research shows that social capital norms in the Serangan sub-district has an important role in tourism development in the Serangan sub-district, where the norms in traditional villages in the Serangan sub-district are still very strong.
\end{abstract}

Keywords: the role of government, community participation, social capital, quality of destinations, community welfare, Serangan sub-district

\section{INTRODUCTION}

Tourism is one of the largest and fastest-growing industries in the world capable of generating economic growth, especially in terms of providing employment, increasing income and living standards, and stimulating the development of other sectors (Neto, 2003). The growing trend of rural tourism in Indonesia is marked by the growing interest in nature-based tourism and an interest in enjoying rural tourism experiences (Sastrayuda, 2010), and the emergence of village tourism. To optimize tourism potential in a tourist village, it is necessary to have local community participation through community empowerment efforts. Community-based tourism (CBT) is a form of tourism destination development through efforts to empower local communities. Community participation is the most important component in efforts to develop independence and the empowerment process (Adiyoso, 2009). The development of tourism villages in Bali was started by the Provincial Government in 1993 with the stipulation of three villages, namely Penglipuran, Sebatu, and Jatiluwih as Tourism Villages by the Governor of Bali (Putra \& Pitana, 2010). Building sustainable tourism is a process that integrates all elements in an area.

Serangan Island as one of the tourism objects in Bali has not escaped the atten- 
tion of many parties, especially those who intend to develop tourism by seeing the potential of the Serangan Sub-District. When viewed physically, before the Serangan Island development project, the total area of Serangan Island was originally $112 \mathrm{hec}-$ tares. Since the attack island development project by PT. Bali Turtle Island Development (BTID), there are very clear changes that have occurred in the shape of the Serangan island. This is due to the addition of land area through the reclamation of 379 hectares so that the total area after being reclaimed becomes 491 hectares. In the context of ecology, Serangan Sub-District has an abundance of panoramic view of the sea and its mangrove forests. Activities related to this are the release of hatchlings and green turtles, foster coral reefs, mangrove planting, as well as the green and marine tourism trails of Serangan. For the education aspect (environmental conservation), traditional and modern cultural arts creativity are held in Serangan Sub-District, Student Green Camp facilities, out-door recreation facilities, and traditional marine technology study centers such as traditional Jukung boats and all their service methods. There are also various activities and hobbies with adventurous nuances such as photography, aeromodelling, fishing, cycling, and trekking.

In its development as a tourist village, Serangan Sub-District has begun to be recognized by both domestic and foreign tourists. From the community side, the existence of community efforts to fight for independence in the management of their resources shows that the community has a strong desire to fight for their rights in managing their village to provide full benefits to the local community of Serangan Sub-District (Suarta, et al., 2017). However, the benefits of developing a Tourism Village in the Serangan Sub-District are not felt by the local community. Also, there is an impact from the existence of several

http://ojs.unud.ac.id/index.php/eot problems related to the tourism destination development project on the environment of the Serangan sub-district which will threaten the sustainability of the Serangan Sub-District tourism destination. In the economic activities of the community, there is also degradation during the reclamation carried out by BTID which causes marine life to decrease so that the catch of fishermen is reduced and of course will cause poverty. In socio-culture, there are also changes in the livelihoods of residents who were initially fishermen trying to switch to the service sector as a result of the tourism development of the Serangan subdistrict (Suryawan \& Gata, 2015). During increasingly fierce destination competition, tourist villages must continue to improve their quality to remain sustainable. This is an obligation to realize tourism development that can provide prosperity not only to local communities but also to tourism industry players and most importantly to provide satisfaction to tourists while still paying attention to the quality of the local environment and culture. Government, community participation, and social capital have very important roles in improving the quality of destinations. The government's role will certainly be in vain if it is not supported by local communities and strong social capital in developing tourism development in the region. The purpose of this study is to identify the role of government in developing sustainable tourism in the Serangan Sub-District, to identify the effect of social capital on destination quality and sustainable tourism development in the Serangan sub-district.

\section{METHODS}

The location of this research is in Serangan Sub-District, Denpasar City which has been a tourist village since 2015 according to the Mayor's Decree No. 188.45 / 472 / HK / 2015 concerning the Designa- 
tion of Tourism Villages in Denpasar City. There is a growing tourism potential in Serangan Sub-District. The potential for natural tourism where Serangan Sub-District is a coastal area and beaches with white sand can attract tourists to come to visit, besides that, with the development of floating cages it is often used for fishing activities by visitors, and the latest in the development of turtle conservation, which is very motivating for tourists. to come to Serangan Sub-District. The potential for cultural tourism where there are sociocultural conditions of the community or legacy, namely conditions of community customs, social conditions of the community, traditional events, and the site of Pura Sakenan. Data collection in this study is conducted using survey method with a questionnaire instrument. This questionnaire describes the characteristics of the respondents, the respondents' perceptions of the role of government, participation, and social capital on destination quality and sustainable tourism development (STD).

\section{RESULT AND DISCUSSION}

The results of this study indicate that the role of the government in the development of the Tourism Village in Serangan Sub-District began with the issuance of Decree No. 188.45 / 472 / HK / 2015 on March 23, 2015, concerning the determination of tourism villages in Denpasar City. The phenomenon of social capital will always develop in the community related to customs and traditions, perceptions and mindsets in community activities. This research stems from the community's perception of what the community feels about the tourism village development program in Serangan Sub-District. The value aspect of social capital is also built from expectations that lead to the cooperative behavior of local communities.

The social capital of trust is a pillar of social capital that is needed to build a foundation of togetherness (Putnam, 1993). Public participation is largely determined by the conditions established by the government in creating trust in the community (Emmer et al., 1993). Communication between residents is crucial to the success of building togetherness in a community. In this case, the Denpasar City Government is a very decisive factor in realizing the foundation of trust in society. Tourism development activities in Serangan Sub-District and other villages that are included in tourist villages in Denpasar City have been increased by the government in line with the current government program which focuses on developing tourism based on culture and local wisdom.

Because of the strong belief of the Serangan community in the government in the development of tourist villages in Serangan is that they encourage local people to be more enthusiastic about participating in this tourism village development program.

The Head of the Serangan SubDistrict, I Made Karma, said that the government's role is very active in this tourism village program.

"The government also formed the POKDARWIS Kelurahan Serangan, where the Tourism Office is also part of the organizational structure as a supervisor. The Denpasar City Government also held training in destination management and hospitality which directly affected the increase in the value of government trust in the eyes of the community. With the increase in the aspect of trust in social capital, it will increase community participation to participate actively in the tourism village program in Serangan Sub-District" Said the village head I Wayan Karma in an interview in November 22, 2019.

According to Made Sedana, Bendesa 
Pekraman Serangan in an in-depth interview, since the issuance of the Tourism Village Decree, which was accompanied by socialization and training in tourism activities from the Denpasar City Tourism Office, the community has begun to be enthusiastic about rebuilding their area after it has collapsed due to reclamation carried out by BTID. a few years ago. Several groups of fishermen no longer depend on their marine products but have also begun to expand into tourism services, such as fishing guests pick-up and drop-off, ferry services from Mertesari Beach, and fishing rental businesses which are now getting busy. With the culinary training program held by the government in collaboration with several hotel schools in Bali, people are also starting to be enthusiastic and brave enough to open a typical culinary business in Serangan Sub-District.

Mr. Made Sedana also said that: "with the improvement of infrastructure and tourism support facilities such as international standard toilets, docks, and well-laid out road access, it also increases public confidence in the seriousness of the government in developing Serangan Sub-District". (Interview on 22 November 2019)

The role of the network in the community and its potential for development is strongly influenced by the demographic characteristics, economic conditions, and social structure of the local community. The network is a component of social capital that can increase the sharing of knowledge and information that can stimulate performance in increasing competitiveness and professional management competence to create effectiveness in the production process.

In this research in the tourist village of Serangan Sub-District, based on the results of in-depth interviews with the head of BUMDA and the Head of the Serangan Sub-District, information was obtained that the government, the private sector, pokdarwis, and community organizations have intensely communicated in various stages of developing a tourist village. Pokdarwis is involved in the preparation of destination tourism products, the government and LPD coordinate to facilitate the capital of the people who run tourism businesses, and the people who coordinate with each other through their respective neighborhood heads are forwarded to traditional villages and sub-districts to make paruman which aims to find solutions and provide input to the pokdarwis in each of these tourism village programs.

After the tourism village products have been prepared, pokdarwis coordinates with the Denpasar City Tourism Office and the travel agency business actors in Denpasar City to help market tourism products in Serangan Sub-District. With this network system, the people of Serangan SubDistrict have high expectations that this tourist village will run and be sustainable.

Norms in social capital are defined as community perspectives that are accepted as rules in documented form, unwritten rules that are accepted as norms in a particular community. Norms will influence togetherness in forming the foundation of social capital which can be a supporting indicator as a guide in developing community-based tourism (CBT) in the Serangan Sub-District. Norms are rules that are accepted as an agreement in society so that they have values that are obeyed by certain communities.

There are several agreements in force in Serangan Tourism Village related to the implementation of more norms from the activities regulated by their customary village.

POKDARWIS secretary Mr. I Wayan Sutarja in an interview on November 27, 2019 said that:

"The community's tourism awareness activities in Serangan Sub-District e-ISSN 2407-392X. p-ISSN 2541-0857 
began with the family environment. This is because the awig-awig (traditional laws) of the customary village about environmental cleanliness in Serangan Sub-District is a little strict. There is a certain schedule when people can take out their trash from the house where the cleaning staff is on standby to pick up the trash. After this predetermined schedule, the community is not allowed to remove rubbish from their yard. Also, the traditional village has a schedule of cooperation every time before certain rerahinan, especially before the pujawali at Sakenan Temple which is coordinated with each respective banjar."

From this statement, it can be illustrated that the social capital norms in traditional villages in Serangan Sub-District are still strong and have an important role in improving the quality of destinations in the Serangan Sub-District, especially in terms of environmental cleanliness. The results of this identification are in line with research conducted by Inayah (2012) which defines that social capital is a resource that arises from the results of interactions in a community, both between individuals and between institutions that give birth to emotional bonds in the form of trust, reciprocity, social networks, values. and norms that shape the structure of society that is useful for coordination and cooperation in achieving common goals.

The research findings presented in this study relate to the role of government, community participation, and social capital on destination quality and the sustainability of tourism destination development in the Serangan Sub-District, where social capital is the basis of strength in realizing community-based tourism that will improve destination quality while supporting sustainability. that destination. There is often miscommunication between the go-

http://ojs.unud.ac.id/index.php/eot vernment and the local community in the development of sustainable tourism in Serangan Sub-District due to a lack of coordination in planning village tourism in Serangan Sub-District.

\section{CONCLUSION}

Based on the results of this study, several things can be suggested as follows. First, the government's role as a dynamist needs to be improved, namely by holding and carrying out harmonious cooperation with the community, the private sector, and tourism business actors in Serangan SubDistrict to improve the quality of tourist destinations in Serangan Sub-District, such as by providing assistance and training. training on destination management, tourism services to village tourism managers in Serangan Sub-District. Second, the Government needs to focus more on managing tourism in the tourism village, namely by taking inventory of existing tourism potential, providing supporting facilities that do not yet exist in the tourist village, helping pokdarwis performance in packaging existing potential into a tourism product that is feasible to be marketed, and empowering and motivating local communities to increase their participation in the development of tourist villages in Serangan Sub-District. Third, the community is advised to increasingly maintain social capital, especially the norms that exist in society in the form of togetherness, the spirit of cooperation, and awareness of tourism behavior. Fourth, it is very necessary to strengthen the tourism village network coordinated by Pokdarwis in collaboration with traditional villages and sub-districts to collaborate with industry parties such as ASITA, HPI, and PHRI, as well as universities and conduct comparative studies with developed tourist villages, there is need for strengthening and increasing the institutional role between customary villages and kelurahan and 
pokdarwis in tourist villages to overcome and find solutions to the obstacles faced in implementing the development of tourism villages in Serangan Sub-District.

\section{REFERENCES}

Adiyoso, W. (2009). Menggugat perencanaan partisipatif dalam pemberdayaan masyarakat. PMN.

Emmer, R. M., Tauck, C., Wilkinson, S., and Moore, R. G. (1993). Using global distribution systems. The Cornell Hotel and Restaurant Administration Quarterly, 34(6), pp. 80-89.

Inayah. (2012). Peran Modal Sosial Dalam Pembangunan, Jurnal Pengembangan Humaniora, 1(1).

Neto, F. (2003). A new approach to sustainable tourism development: Moving beyond environmental protection. In Natural Resources Forum (Vol. 27, No. 3, pp. 212-222). Oxford, UK: Blackwell Publishing Ltd.

Putnam, R. (1993). The prosperous com- munity: Social capital and public life. The american prospect, 13(Spring), Vol. 4. Available online: http://www. prospect. org/print/vol/13 (accessed 7 April 2003).

Putra, I. N. D. and Pitana, I. G. (2010). Pariwisata pro-rakyat: meretas jalan mengentaskan kemiskinan di Indonesia. Kementerian Kebudayaan dan Pariwisata.

Sastrayuda, G. S. (2010). Konsep pengembangan kawasan desa wisata', Bandung (ID): Universitas Pendidikan Indonesia.

Suarta, I. K., Swabawa, A. A. P. and Budiarta, I. P. (2017). Potensi Daya Tarik Wisata Bahari di Desa Serangan Denpasar', in Prosiding Sentrinov (Seminar Nasional Terapan Riset Inovatif), pp. EB328-EB337.

Suryawan, N., and Gata, I. W. (2015). Keterpinggiran Nelayan Dalam Pembangunanpariwisata Di Kelurahan Serangan, Denpasar Selatan. In Seminar Nasional Riset Inovatif (Vol. 3). 